\title{
Employees in Ghana Attitude toward the Marketing Concept Operation in Organizations
}

\author{
Benjamin Tawia Ansu1, Kwabena Obeng-Asare ${ }^{2}$ \\ ${ }^{1,2}$ Sunyani Polytechnic, School of Business and Management, Sunyani, Ghana
}

\begin{abstract}
The implementation of the Structural Adjustment Programme in the late 1980s and 1990s has transformed the Ghanaian business environment from a planned to a market economy. To achieve their business objectives organizations in Ghana need to monitor and respond to customers' changing needs and preferences to ensure that customers select their offerings over competing alternatives. This in turn requires these organizations to accept marketing as a strategic concept in their operations. The review of the marketing literature does not provide any evidence of employees' opinion profile of the marketing concept as perceived from organizations in Ghana perspective. This paper intends to fill this gap by replicating the work of Barksdale and Darden, which provides a useful framework for analyzing individual attitudes toward the marketing concept following an evolutionary path as reflected in the literature. The purpose is to establish different aspects of the marketing concept operation in business organizations as perceived from employees' perspective. The researchers report the results of a survey of 65 employees' selected randomly, designed to measure the dimensions of the concept to provide opinion profile of its operational adequacy, influence on management, and its contributions to business, and consumers in Ghana. The study concludes that although the marketing concept operates in businesses in Ghana, there is the need to undertake in-depth study of the concept to understand how it is being applied by organizations.
\end{abstract}

Keywords: Marketing Concept, Corporate Philosophy, Customer Orientation, Attitude, Consumerism

\section{Introduction}

The implementation of the Structural Adjustment Programme during the late 1980s and 1990s has transformed the Ghanaian business environment from a planned to a market economy [1]. As a result, organizations in Ghana needed to learn, like their international competitors, to monitor and respond to customers' changing needs and preferences to ensure that customers select their offerings over competing alternatives in order to achieve their market objectives. This in turn requires these organizations to accept marketing as a strategic concept that places the customer at the very centre of an organization"s operations [4]. A review of the available literature reveals that with few exceptions, major studies on the marketing concept have been limited to the developed countries [9], and is yet to be researched in the academic circles in Ghana. In this connection it could be argued that there is still the need to investigate and understand the attitude and opinions of employees towards the concept in organizations.

The marketing concept is based on two fundamental notions [14]: First the consumer is recognized as the focal point or pivot for all business activity. Second, profit- rather than sales volume is specified as the criterion for evaluating marketing activities. The basic ideas embodied in the marketing concept as defined in this context are generally understood and intuitively practiced by many successful business firms. The marketing concept also has been described by different authors as a corporate state of mind or philosophy that insists on the integration and coordination of all of the marketing functions which, in turn, are melded with other corporate functions, for the basic objective of producing maximum long-range corporate profits [5]. It is this marketing philosophy which proposes that the business focus on the consumer's needs and desires [11].
According to McGee and Spiro [10] marketing writers generally describe this focus in three parts. The first part looks at customer orientation, which is knowledge of the customer, requiring a thorough understanding of his needs, wants, and behavior, and should be the focal point of all marketing action. The second part is integrated effort, which ultimately, requires that the entire firm must be in tune with the market by emphasizing the integration of the marketing function with research, product management, sales, and advertising, thus enhancing the firm's total effectiveness. The final part is the profit direction, which is intended to make money for the company by focusing attention on profit rather than on sales volume. As a philosophy of marketing is directed toward the long run, it thus encourages businesses to look at basic consumer needs rather than at transient products [10]. There exists widespread belief that investigating the attitude of employees in organizations uncovers the extent to which the marketing concept is practiced in organizations to achieve their market objectives. Barksdale and Darden [3] have provided a useful conceptual framework for analyzing marketer"s attitude toward the marketing concept, which serves basis for this study.

Attitude as a concept has long been of critical importance in attempts to explain man"s social behaviour [13]. According to Solomon et al [12] attitude could be viewed as both theoretical concept and a tool to be used in the market place, an issue of prime importance to marketers. As a concept it has no one absolute and correct meaning [13]. Most researchers agree that an attitude has three components: cognition, affect and behaviour [12]. Cognition refers to the beliefs a person has about an attitude object; affect refers to a person "s feelings; and behaviour involves intentions to do something with regard to the object. Employees"e attitude toward marketing concept in this research imply observations that involve these three components. 


\section{International Journal of Science and Research (IJSR) \\ ISSN (Online): 2319-7064}

Index Copernicus Value (2013): 6.14 | Impact Factor (2014): 5.611

\section{The Conceptual Framework}

Following an evolutionary path as reflected in the literature, Barksdale and Darden [3] suggest four categories that require detailed analysis which is discussed below:

- Concept Dimensions and adequacy

- Influence on management

- Consumer benefits

- The Marketing concept and consumerism

Concept dimensions and adequacy: The logic of the marketing concept is that a firm that focuses all its efforts toward profitable satisfaction of consumer needs and wants will be rewarded with repeated consumer purchases. Mitchell and Agenmonmen [11] argued that because consumers' needs, wants and market niches are constantly in an evolutionary state, the dimension and adequacy of the concept as perceived from organizations" perspective need updating. They pointed out that these changes are speeded up by the twin forces of international product competition and intra-national competitive turbulence as products proceed through various stages of their life cycles.

Influence on management: Mitchell and Agenmonmen [11] argued that because, it is generally thought that, the marketing concept is an academic idea that may work better in theory than in practice, potential influence on management may be paramount. The basic tenet of the marketing concept is to focus on long-term profit through customer satisfaction [4]. In order to sustain this position, corporate effort needs to be devoted to detailed planning, organizing, and controlling of marketing activities. Understanding the nature of management's influence is important because it tends to establish the yardstick upon which consumer benefits will be provided

Consumer benefits: As company operations become more customer-oriented in philosophy, company executives grow more in tune with operating a marketing system based on consumer benefits [4]. Barksdale and Darden [3] survey study revealed that majority of executives and educators believe that the concept provides insights into the operation of the marketing system and has helped make the system more responsive to consumer wants. In addition, the marketing concept has been instrumental in creating specific benefits for consumers as it has encouraged manufacturers to design products according to the dictates of consumers.

The marketing concept and consumerism: Consumerism is organized action against business practices that are not in the interest of consumers [7]. Mitchell and Agenmonmen [11] observed that the rise of consumerism may represent a manifestation of the irrefutable logic of marketing dialectics. They argued that the proper application of the marketing concept philosophy may prevent the rise of consumerism. They also argued that its implementation after the rise of consumerism may also reduce the need for the latter. Barksdale and Darden [3] study revealed that almost all respondents (91.6\%) agree that consumerism would be an expanding challenge to those concerned with marketing and that there was the need for government regulation to protect consumers' interests.

\section{Methodology}

Following the lead by previous researchers approach to this area of a study [11;3], the present work adopted the quantitative method to collect data for this study. A census type of survey technique was employed in this study to measure the opinion profile of employees" attitude toward the marketing concept questionnaire items. Respondents were selected randomly from a population made up of employees in organizations that the researchers personally approached. In all a sample size of 115 was selected for the study. The employees selected were made up of managers, marketing managers and lecturers, MBA management and marketing students working in various organizations in the Brong Ahafo and Ashanti Regions, Ghana. The selection of samples corresponds broadly to that suggested by Kohli and Jaworski [8] in the selection of samples when construction theory to tap a wide range of experiences and perspectives in the course of the data collection. Out of the 115 questionnaires, 68 were retrieved, a response rate of 59.13\%. Of the 68 questionnaires that were retrieved, 3 were rejected because of too much missing data, which left $56.52 \%$ (65) usable responses.

The questionnaire for data collection is a modification of previously used Likert scales developed by Barksdale and Darden [3]. The reliability of the scales tends to be good as a greater range answers is permitted to respondents. The questionnaire was made up of 29 "Likert-type" statements. Respondents were asked to score each statement along a fivepoint scale, ranging from "strongly agree" to "strongly disagree." For purposes of analysis and discussion, the 29 statements are grouped into the following four categories; (1) Concept Dimensions and Adequacy, (2) Influence on Management, (3) Consumer Benefits, and (4) The Marketing Concept and Consumerism.

\section{Analysis of Results}

Analysis is directed towards assessing the respondents ${ }^{\text {ee }}$ attitude toward the marketing concept in the Ghanaian businesses $^{\text {ee }}$ operations. Descriptive statistics, specifically percentages presented in tables, are used to highlight the research findings in order to compare results with previous studies. It is worth noting that previous studies used percentages and tables to present the results of analysis [11;3]. This approach of presenting research data is in line with Bell [2]. suggestion that "in many projects and theses, it will be sufficient to understand simple arithmetical procedures such as averages and percentages" to serve as basis for interpreting the evidence and reporting findings (p. 201). 


\section{International Journal of Science and Research (IJSR) \\ ISSN (Online): 2319-7064}

Index Copernicus Value (2013): 6.14 | Impact Factor (2014): 5.611

Table 1: Concept Dimensions and Adequacy

\begin{tabular}{|c|c|c|c|c|c|c|}
\hline \multirow[b]{2}{*}{ Statement } & \multicolumn{6}{|c|}{ Level of Agreement } \\
\hline & Respondents & $\begin{array}{l}\text { Strongly } \\
\text { Disagree }\end{array}$ & Disagree & Uncertain & Agree & $\begin{array}{l}\text { Strongly } \\
\text { Agree }\end{array}$ \\
\hline $\begin{array}{l}\text { 1.Stated simply, the marketing concept holds (1) that all business } \\
\text { decisions-including marketing decisions-must be consumer } \\
\text { oriented, and (2) profit rather than sales should be the standard } \\
\text { for evaluating marketing performance }\end{array}$ & \multirow{6}{*}{$\begin{array}{l}(65 \\
\text { respondents } \\
100 \%)\end{array}$} & 1.54 & 9.23 & 1.54 & 41.54 & 46.15 \\
\hline $\begin{array}{l}\text { 2. The Basic ideas of the marketing concept are equally valid for } \\
\text { both large and small business firms }\end{array}$ & & 1.54 & 4.62 & 4.62 & 33.85 & 55.38 \\
\hline $\begin{array}{l}\text { 3. The Marketing concept is an academic idea that works better } \\
\text { in theory than in practice }\end{array}$ & & 15.38 & 40 & 12.31 & 21.54 & 10.77 \\
\hline $\begin{array}{l}\text { 4. The motion of consumer orientation is so general and vague } \\
\text { that it is inadequate as a decision criterion in the day-to-day } \\
\text { management of marketing activities. }\end{array}$ & & 20 & 30.77 & 23.08 & 23.08 & 3.08 \\
\hline $\begin{array}{l}\text { 5.In actual practice, there are frequent conflicts between } \\
\text { consumer orientation and profit objectives }\end{array}$ & & 6.15 & 9.23 & 7.69 & 64.62 & 12.31 \\
\hline $\begin{array}{l}\text { 6. In the event of conflicts between consumer orientation and } \\
\text { profit objectives, profits would be the overriding consideration }\end{array}$ & & 4.62 & 13.85 & 16.92 & 38.46 & 26.15 \\
\hline
\end{tabular}

\subsection{Concept Dimensions and Adequacy}

Table 1 (above) reports the analysis of respondents" ratings of the marketing concept dimensions and adequacy, which is made up of six questionnaire items. The definition of the concept "holds that all business decisions - including marketing decisions - must be consumer oriented, and profit rather than sales should be the standard for evaluating marketing performance". Majority of respondents, $87.69 \%$ $(41.54 \%+46.15 \%)$ either strongly agreed or agreed with this statement. Only $10.77 \%(1.54 \%+9.23 \%)$ of the respondents either strongly disagreed or disagreed whiles $1.54 \%$ were neutral about the statement. A question (item 2) that was posed to find out whether the basic ideas of the marketing concept are equally valid for both large and small business firms indicated that $89.23 \%$ either strongly agreed or agreed with this statement, while $6.16 \%$ either strongly disagreed or disagreed and just $4.62 \%$ were uncertain about this statement. Questionnaire item 3 that states that "the marketing concept is an academic idea that works better in theory than in practice", revealed that majority of the respondents, $55.38 \%$, disagreed that the marketing concept is an academic idea that works better in theory than in practice. 33.31\%, however, agreed with the statement while $12.31 \%$ were uncertain.

Moreover, $50.77 \%$ of the respondents strongly disagreed or disagreed with the statement that "the motion of consumer orientation is so general and vague that it is inadequate as a decision criterion in the day-to-day management of marketing activities", while $26.16 \%$ either agreed or strongly agreed, with $23.08 \%$ remaining uncertain of the statement. Statement 5 which suggest that in actual practice, there are frequent conflicts between consumer orientation and profit objectives, $76.93 \%$ either strongly agreed or agreed, with $15.38 \%$ of the respondents disagreed with the suggestion whiles those who were uncertain accounted for only $7.69 \%$. With regard to questionnaire item 6 (see Table1), while $64.61 \%$ of the respondents agreed or strongly agreed, $18.47 \%$ either disagreed or strongly disagreed, with only $16.92 \%$ uncertain with the statement.

\subsection{Influence on Management}

The statistics in Table 2 shows the result of the questions attempting to evaluate the influence of the marketing concept on management. In relation to statement 7 , while $67.69 \%$ of the respondents thought that the marketing concept has been adopted as an operating philosophy by most business firms in Ghana, $21.54 \%$ either strongly disagreed or disagreed with the statement. Only $10.77 \%$ were uncertain as to whether the concept has indeed been adopted. In response to item 8 a significant number of respondents, $82.82 \%$, agreed or strongly agreed that over the past twenty years, the marketing concept has had tremendous influence on the philosophy and thought of top management in the leading business firms of Ghana. 


\section{International Journal of Science and Research (IJSR) \\ ISSN (Online): 2319-7064}

Index Copernicus Value (2013): 6.14 | Impact Factor (2014): 5.611

Table 2: Influence on Management

\begin{tabular}{|l|c|c|c|c|c|}
\hline \multicolumn{1}{|c|}{ Statement } & \multicolumn{3}{|c|}{ Level of Agreement } \\
\cline { 5 - 7 } & Respondents & $\begin{array}{l}\text { Strongly } \\
\text { Disagree }\end{array}$ & Disagree & Uncertain & Agree \\
Agree
\end{tabular}

Out of the 65 respondents only $4.69 \%$ were uncertain, while $12.5 \%$ either strongly disagreed or disagreed with the statement. 51\% respondents either agreed or strongly agreed to the claim (item 9) that executives have given considerable lip service to the marketing concept, and that in general it has had little influence on the day-to-day management of marketing activities. A significant number of respondents (36.92\%), however, either strongly disagree or disagree with the claim, while $12.31 \%$ were uncertain. In response to questionnaire item 10 stating that the marketing concept has had its greatest influence within the business firm- on the organization and management of marketing activities majority of the respondents, 76.92\%, either strongly agreed or agreed to the statement. Only $13 \%$ either strongly disagreed or disagreed while $9.23 \%$ were uncertain.

In response to item 11 which stated that "the marketing concept has brought about a more logical and effective organizational arrangement of marketing activities within the business firms ${ }^{\text {ee }}$, quite significantly number of respondents, $75.38 \%$ either strongly agreed or agreed to the statement as compared with only $13.85 \%$ who took the opposite view, while $10.77 \%$ of the respondents were not certain.

When the respondents were asked to rate the statement (item 12) that ,the marketing concept has made marketing executives more profit minded and increased their involvement with company profit objectivesee, $67.69 \%$ of them either strongly agreed or agreed to the statement.

$16.92 \%$ respondents disagreed while $15.38 \%$ remained in the neutral position. On the suggestion that the marketing concept has increased the attention and efforts devoted to planning and controlling marketing activities, $90.77 \%$ of the respondents either strongly agreed or agreed to this suggestion (item 13).

Only 3.08\% disagreed to this statement with $6.15 \%$ selecting neutral response. Item 14 which also states that "if measured in terms of its contributions to the management of marketing activities within the business firm, the marketing concept has proven effective", $80 \%$ of the sample agreed or strongly agreed to this statement. 


\section{International Journal of Science and Research (IJSR) \\ ISSN (Online): 2319-7064 \\ Index Copernicus Value (2013): 6.14 | Impact Factor (2014): 5.611}

Table 3: Consumer Benefits

\begin{tabular}{|c|c|c|c|c|c|c|}
\hline \multirow{2}{*}{ Statement } & \multicolumn{6}{|c|}{ Level of Agreement } \\
\hline & Respondents & $\begin{array}{l}\text { Strongly } \\
\text { Disagree }\end{array}$ & Disagree & Uncertain & Agree & $\begin{array}{l}\text { Strongly } \\
\text { Agree }\end{array}$ \\
\hline $\begin{array}{l}\text { 15. Since time in memorial, the adoption and implementation of } \\
\text { the marketing concept has been the single most important } \\
\text { development in Ghanaian marketing. }\end{array}$ & \multirow[t]{9}{*}{ (65)100\% } & $4.62 \%$ & $38.46 \%$ & $26.15 \%$ & $21.54 \%$ & $9.23 \%$ \\
\hline $\begin{array}{l}\text { 16. From the stand point of consumers, the marketing concept has } \\
\text { produced relatively few benefits. }\end{array}$ & & 7.69 & 35.38 & 21.54 & 24.62 & 10.77 \\
\hline $\begin{array}{l}\text { 17. The marketing concept offers little, if any, insight into the } \\
\text { overall operation of the marketing system and the benefits it } \\
\text { provides society }\end{array}$ & & 13.85 & 41.54 & 21.54 & 18.46 & 4.62 \\
\hline $\begin{array}{l}\text { 18. The marketing concept has encouraged manufacturers to } \\
\text { design products which fit more precisely the needs and wants of } \\
\text { consumers. }\end{array}$ & & 0 & 3.08 & 12.31 & 38.46 & 46.15 \\
\hline $\begin{array}{l}\text { 19. The marketing concept has forced advertising and personal } \\
\text { selling to become more informative to consumers. }\end{array}$ & & 1.54 & 3.08 & 4.62 & 56.92 & 33.85 \\
\hline $\begin{array}{l}\text { 20. The marketing concept has stimulated manufacturers to alter } \\
\text { distribution channels in order to match product availability more } \\
\text { closely with consumer shopping habits. }\end{array}$ & & 0 & 3.08 & 10.77 & 56.92 & 29.23 \\
\hline $\begin{array}{l}\text { 21. The Marketing concept has been major factor in raising the } \\
\text { quality of service provided consumers both before and after sale } \\
\text { the Transaction. }\end{array}$ & & 1.54 & 9.23 & 13.85 & 50.77 & 24.62 \\
\hline $\begin{array}{l}\text { 22. When evaluating in terms of the actual benefits created for } \\
\text { consumers in the marketplace, the marketing concept must be } \\
\text { judged a failure }\end{array}$ & & 24.62 & 43.08 & 15.38 & 13.85 & 3.08 \\
\hline $\begin{array}{l}\text { 23. The marketing concept has been an important factor in } \\
\text { making the marketing system more responsive to consumers } \\
\text { wants. }\end{array}$ & & 1.54 & 6.15 & 7.69 & \begin{tabular}{|l|}
53.85 \\
\end{tabular} & 30.77 \\
\hline
\end{tabular}

On the other hand $20 \%$ respondents either strongly disagreed or disagreed to the statement with no one selecting the neutral response.

\subsection{Consumer Benefits}

Table 3 displays the results of the questions attempting to determine whether the concept as practiced in organizations is benefiting consumers. There was mixed response from the respondents to item 15 which stated that "since time in memorial, the adoption and implementation of the marketing concept has been the single most important development in Ghanaian marketing". A significant number of $43.08 \%$ either disagreed or strongly disagreed with the statement, while $30.77 \%$ either agreed or strongly agreed and sizable number of respondents (26.15\%) remaining uncertain about the statement. Similarly, $43.07 \%$ of those who responded to statement 16 either disagreed or strongly disagreed with the statement that the marketing concept has produced relatively few benefits from the consumers ${ }^{\text {ee }}$ perspective. Those who were in agreement with the statement were $35.39 \%$ respondents and $21.54 \%$ were uncertain.

With respect to the assertion (item 17) that "the marketing concept offers little, if any, insight into the overall operation of the marketing system and the benefits it provides society", $55.39 \%$ either disagreed or strongly disagreed with the statement, whereas only $23.08 \%$ either agreed or strongly agreed with it. $21.54 \%$ were uncertain of the statement. However when the sample opinions were sought on the issue whether "the marketing concept has encouraged manufacturers to design products which fit more precisely the needs and wants of consumers" (item 18) 84.61\% either strongly agreed or agreed, while only $3.08 \%$ were in disagreement with the statement and $12.31 \%$ remaining uncertain.

Table 4: The marketing Concept and Consumerism

\begin{tabular}{|c|c|c|c|c|c|c|}
\hline \multirow[b]{2}{*}{ Statement } & \multicolumn{6}{|c|}{ Level of Agreement } \\
\hline & Respondents & $\begin{array}{l}\text { Strongly } \\
\text { Disagree }\end{array}$ & Disagree & Uncertain & Agree & $\begin{array}{c}\text { Strongly } \\
\text { Agree }\end{array}$ \\
\hline $\begin{array}{l}\text { 24. The rise of consumerism is an expanding challenge to all } \\
\text { concerned with marketing. }\end{array}$ & \multirow{4}{*}{ (65)100\% } & 0 & 7.69 & 13.85 & 47.69 & 30.77 \\
\hline $\begin{array}{l}\text { 25. The spread of the marketing concept and the rise of } \\
\text { consumerism are separate and unrelated developments. }\end{array}$ & & 24.62 & 36.92 & 23.08 & 7.69 & 7.69 \\
\hline $\begin{array}{l}\text { 26. The rapid rise of consumerism over the last decade is a } \\
\text { reflection of the inadequacy of the marketing concept }\end{array}$ & & 7.69 & 35.38 & 27.69 & 26.15 & 3.08 \\
\hline $\begin{array}{l}\text { 27. If the marketing concept were Properly applied by } \\
\text { business firms, consumerism would Subside. }\end{array}$ & & 7.69 & 24.62 & 32.31 & 27.69 & 7.69 \\
\hline
\end{tabular}




\section{International Journal of Science and Research (IJSR) \\ ISSN (Online): 2319-7064 \\ Index Copernicus Value (2013): 6.14 | Impact Factor (2014): 5.611}

28. Most consumers do not understand or appreciate the efforts made by manufacturers and dealers to satisfy their needs and wants.

29. For the protection of consumers marketing activities must be more carefully regulated and controlled by government agencies.

\begin{tabular}{|l|l|l|l|l|}
6.15 & 21.54 & 10.77 & 49.23 & 12.31 \\
\hline 4.62 & 18.46 & 6.15 & 35.38 & 35.38 \\
\hline
\end{tabular}

Similarly, in responding to item $19,90.77 \%$ indicated that they either agree or strongly agree with the statement that the marketing concept has forced advertising and personal selling to become more informative to consumers. Only $4.62 \%$ either disagreed or strongly disagreed to the statement, with just $4.62 \%$ remaining uncertain.

Moreover, majority of the sample (86.15\%) were of the view that the marketing concept has stimulated manufacturers to alter distribution channels in order to match product availability more closely with consumer shopping habits (items 20), while only $3.08 \%$ disagreed with the statement, and $10.77 \%$ remaining uncertain. In response to the statement that "the marketing concept has been major factor in raising the quality of service provided for consumers both before and after sale the transaction" (item 21), $75.39 \%$ of the sample either agreed or strongly agree to the statement. Just $10.77 \%$ either disagreed or strongly disagreed with it and 13.85\% were uncertain. When respondents were asked to score item 22 that "when evaluating in terms of the actual benefits created for consumers in the marketplace, the marketing concept must be judged a failure" only $16.93 \%$ either agree or strongly agree with the statement. Majority, (67.7\%) either disagreed or strongly disagreed to the statement, and $15.38 \%$ were uncertain. Finally, scoring item 23 which states that the marketing concept has been an important factor in making the marketing system more responsive to consumers "e wants, a sizable number of respondents (84.62\%) either agreed or strongly agreed to the statement, whereas only $7.69 \%$ either disagreed or strongly disagreed and $7.69 \%$ remained uncertain.

\subsection{The Marketing Concept and Consumerism}

Table 4 below presents responses to items designed to profile respondent 's $^{\circ}$ opinions on the issues concerning consumerism and its relationship to the marketing concept.

On the issue of whether the rise of consumerism is expanding challenge to all concerned with marketing, majority of the respondents (78.46\%) accepted this statement. $13.85 \%$ of the respondents were uncertain while only $7.69 \%$ disagreed.

Although quite a lot of the respondents (23.08\%) were uncertain with the statement that the spread of the marketing concept and the rise of consumerism are separate and unrelated developments (item 25), majority of the respondents (61.54\%) either disagreed or strongly disagreed with the statement. Only $15.38 \%$ were in agreement with the statement.

To the suggestion that the rapid rise of consumerism over the last decade is a reflection of the inadequacy of the marketing concept (item 26) $43.07 \%$ of respondents either strongly disagreed or disagreed with the statement. Only 29.23\% of the total respondents either strongly agreed or agreed while $27.69 \%$ were uncertain about the statement. Majority of the respondents (35.38\%) were in agreement with the statement (item 27) that a proper application of the marketing concept would make the rise of consumerism subside, while 32.31\% of respondents either strongly disagreed or disagreed. However, significant number respondents (32.31\%) and who were uncertain was recorded in respect to the statement. It is also the opinion of the majority of respondents $(61.54 \%)$ that most consumers do not understand or appreciate the efforts made by manufacturers and dealers to satisfy their needs and wants.

In spite of that, $27.69 \%$ of the respondents either strongly disagreed or disagreed with the statement whereas $10.77 \%$ remained uncertain. The response to item 29 indicate that a majority of the respondents (61.54\%) either strongly agreed or agreed with the suggestion that marketing activities must be more carefully regulated and controlled by government agencies for the protection of consumers. However, 23.08\% of the respondents either strongly disagreed or disagreed with statement and $6.15 \%$ were not certain.

\section{Discussion}

\subsection{Concept Dimension and Adequacy}

The marketing concept dimensions and adequacy were made up of six questionnaire items. On the definition of the marketing concept (item 1) 87\% of the respondents were in agreement with the statement. This result suggest that employees selected for the study believe that the definition as given in textbooks is adequate for defining marketing operations in organizations in Ghana. This results supports the study of Mitchel and Agenmonmen, [3] conducted in Nigeria, which indicated that $81.6 \%$ of respondents either strongly agreed or agreed with the definition. On the issue of whether the basic ideas of the marketing concept are equally valid for both large and small business firms $89.23 \%$ either strongly agreed or agreed with the statement (item 2). This result is an evidence to indicate that employees in Ghana were of the opinion that the concept could be applied to business organizations activities and that size is not determining factor. These observations study confirms the work of Mitchel and Agenmonmen [11] and Barksdale and Darden [3] who had $83.1 \%$ and $93.7 \%$ respectively agreeing with the statement.

On issue of whether (item 3) the marketing concept is an academic idea that works better in theory than in practice, 15 $\%$ of the respondents strongly disagreed, while $40 \%$ simply disagreed agreed with the statement (a total of 55.38 percent). This response indicates that the marketing concept 


\section{International Journal of Science and Research (IJSR) \\ ISSN (Online): 2319-7064}

Index Copernicus Value (2013): 6.14 | Impact Factor (2014): 5.611

work in practice when it is applied to an organizations marketing efforts. This finding also supports Mitchel and Agenmonmen [11] and Barksdale and Darden [3], who had of 63.1 percent and 74 percent respectively of the respondents either strongly disagreeing or disagreeing with the statement.

Although $50.77 \%$ of a the respondents strongly disagreed or disagreed with the statement with the statement that consumer orientation is inadequate as a criterion for day-today marketing decisions, Barksdale and Darden [3] work in USA and Mitchel and Agenmonmen [11] in Nigeraia had $63 \%$ and $56 \%$ respectively, who either strongly disagreed or disagreed with the statement. These observations suggest that consumer orientation is adequate as a criterion for day-to-day marketing decisions in business organizations.

Statement 5 which suggest that in actual practice, there are frequent conflicts between consumer orientation and profit objectives, $76.93 \%$ either strongly agreed or agreed with it. Likewise, $75.4 \%$ either agreed or strongly agreed to this statement in the study conducted by Mitchel and Agenmonmen [11]. However, in the work of Barksdale and Darden (1971) 57\% were in agreement with this statement. Although this variation in opinion could not be determined in the data, it could suggest USA respondents experience with the concept operation in their organizations for some decades.

The analysis of the data also revealed that majority of respondents (64.61\%) agreed or strongly agreed to the suggestion that profit should be an overriding consideration in the event of a conflict between consumer orientation and profit objectives (item 6). Barksdale and Darden [3] respondents responded with the same relative frequency over all answer categories with no significant differences in their responses. Likewise, there was no significant difference in the responses the same statement in Mitchel and Agenmonmen [11].

\subsection{Influence on Management}

In relation to statement 7 , while $67.69 \%$ of the respondents thought that the marketing concept has been adopted as an operating philosophy by most business firms in Ghana, in contrast, in the USA study only $26.3 \%$ thought the concept has been adopted by businesses. Also in the Nigeria study 47.1 either agreed or strongly agreed to this statement. Though the studies conducted in Nigeria and USA were done long time ago, this responses raises the question whether in Ghana employeese opinions actually reflects the concept as it is practiced in businesses. The employees scores further raises other questions when responses related to the respondents who were uncertain whether the concept is adopted or not. In the USA a sizable number respondents, $32.2 \%$ were uncertain as compared with Nigeria study, $20 \%$ and Ghana only $10.77 \%$, which were mixed results.

In reaction to item 8 a significant number of respondents, $82.82 \%$, agreed or strongly agreed that over the past twenty years, the marketing concept has had tremendous influence on the philosophy and thought of top management in the leading business firms of Ghana. Comparing the employees in Ghana responses with that of Nigeria and USA studies, although in both studies majority of respondents reaction were positive $70.4 \%$ and $58.5 \%$ respectively, the current study of respondents in Ghana was highly significant.

Although $51 \%$ of the respondents either agreed or strongly agreed that executives have given considerable lip service to the marketing concept, and that in general it has had little influence on the day-to-day management of marketing activities as indicated in statement 9, the response was not significant. Mitchel and Agenmonmen study also had majority of responses, $64.7 \%$, to this statement, while Barksdale and Darden work shoed much lower percentage, $22.1 \%$. These results suggest that respondents in Ghana and Nigeria study believe that executives have given considerable lip service to the marketing concept in day-to-day management of marketing activities. This is supported by number of respondents who either strongly disagree or disagree with the claim in Ghana (36.92\% out of the total respondents $12.31 \%$ were uncertain) and Nigeria (30.7\% and $4.6 \%$ respectively).

With regard to questionnaire item 10 , which stated that the marketing concept has had its greatest influence within the business firm - on the organization and management of marketing activities, majority of the respondents, $76.92 \%$, either strongly agreed or agreed to this statement. This result compares favourably with Mitchel and Agenmonmen [11] and Barksdale and Darden [3], who had 70.8\% and 69. 20\% respectively, suggesting that the concept has had its greatest influence within the business firm (that is, on the organization and management of marketing activities in these three countries despite the time lapse between these studies and the location differences).

An obvious trend in the data was the high level of respondents in Table 2 indicating that they either strongly agreed or agreed with all the statements, with the exception of item 9, which had a score $50.77 \%$, that showed that the marketing concept has influence on management. This high level of response ranges from $67.69 \%$ (item 7) to $90.77 \%$ (item 13). For example these statements indicated that ,the marketing concept has made marketing executives more profit minded and increased their involvement with company profit objectivese (item 13, 90.77\%); and also that „over the past twenty years, the marketing concept has had tremendous influence on the philosophy and thought of top management in the leading business firms of Ghana ${ }^{e c}$ (item 8, 82.82\%).This result in Ghana also positively confirms the other two studies in Nigeria and USA. In the Nigeria and USA studies respondents rated item 13, 89.3\%; 90.4\%, and item 8, 58.5\%; 70.4\% respectively. However, statement 7 results in the Nigeria (46.1\%) and USA (26\%) research were in contrast with that of Ghana (67.69).

\subsection{Consumer Benefits}

In an attempt to determine the perceived benefits of the marketing concept to the consumers ${ }^{\text {ee }}$ majority $(43.08 \%)$ of respondents were in disagreement with the statement 15 that the adoption and implementation of the marketing concept has been the single most important development in Ghanaian

\section{Volume 5 Issue 3, March 2016}




\section{International Journal of Science and Research (IJSR) \\ ISSN (Online): 2319-7064}

Index Copernicus Value (2013): 6.14 | Impact Factor (2014): 5.611

marketing. This result was not significant in the sense that $30.77 \%$ of respondents also either agreed or strongly agreed with the statement. What is significant about this statement is that a sizable number of respondents (26.15\%) were uncertain, thus indicating a mixed response for the statement. The current study in the context of Ghana confirms positively the results obtained by Mitchel and Agenmonmen [11] study of the concept in Nigeria - the respondents who disagreed or strongly disagreed 40.1\%; strongly agreed or agreed 38.4; and uncertain $26.2 \%$.

Respondents score for statement 15, is reflected in responses to statements 16 and 17, which stated that the marketing concept has produced relatively few benefits from the consumers perspective and that the marketing concept offers little, if any, insight into the overall operation of the marketing system and the benefits it provides society respectively. The results indicated that those either disagreed or strongly disagreed with the statements 16 and 17 were $43.07 \%$ and $55.39 \%$ respectively, while those who either strongly agreed or agreed were $35.39 \%$ and $23.08 \%$.

With the statements that the marketing concept has encouraged manufacturers to design products to fit more precisely the needs and wants of consumers (item 18); forced advertising and personal selling to become more informative to consumers (item 19); stimulated manufacturers to alter distribution channels in order to match product availability more closely with consumer shopping habits (item 20); been major factor in raising the quality of service provided consumers both before and after sale the Transaction (item 21); and been an important factor in making the marketing system more responsive to consumerse wants (item 23), majority of respondents either agreed or strongly agreed with these statements, namely, 84.6, 90.77, 86.15, 75.39, and $84.62 \%$ respectively. These statements suggest that respondents in Ghana strongly perceived the operation of the marketing concept in Ghanaian organizations as benefiting the consumers.

It is worth noting that even statement 22 which majority of respondents (67.7\%) disagreed or strongly disagreed did suggested strongly that the respondents were of the view that the concept is benefiting the consumers in Ghana. This statement sought to point out that,when evaluating in terms of the actual benefits created for consumers in the marketplace, the marketing concept must be judged a failuree, which was not accepted by the respondents. Even it could be argued that statements 15, 16 and 17 support the same view. The current study once again could be said that it supports the Nigeria and USA studies conducted in 1994 and 1971 respectively.

\subsection{The Marketing Concept and Consumerism}

The questionnaire items in this section were designed to examine respondents ${ }^{\text {ee }}$ view regarding the challenge of consumerism, the relations between consumerism and the marketing concept, and the need for government regulation to protect consumers' interests. Majority of the respondents (78.46\%, item 24) indicated and agreed that consumerism will be an expanding challenge to those concerned with marketing. However, majority of respondents (61.54\%, item 25) disagreed to the statement that the spread of the marketing concept and the rise of consumerism are unrelated developments in Ghana. These results for the two questionnaire items support the findings of Mitchel and Agenmonmen [11] and Barksdale and Darden [3] studies in Nigeria and USA respectively. While respondents in Nigeria either agreed or strongly agreed with item 24 (89.7\%) and that $63.1 \%$ either disagreeing or strongly disagreeing to item 25 , the USA results indicated $91.6 \%$ (item 24) and $61.5 \%$ (item) respectively.

The results of respondents in Ghana were not clear cut when the study (statement 26) sought to find their opinion on the issue that the rapid rise of consumerism over the last decade is a reflection of the inadequacy of the marketing concept. $43.07 \%$ of respondents were in disagreement with the statement, $29.23 \%$ either strongly agreed or agreed while a significant number of them (27.69\%) were uncertain about the statement. The result was similar in the Nigeria 1994 study but contrasted with that of the USA study in 1971, which had $65 \%$ of respondents disagreeing with the statement.

Statement 27 results followed the same trend as reflected item 26 responses. Out of 65 respondents 35.38\% agreed to the assertion that if the marketing concept were properly applied by business firms, consumerism would subside. A significant number of respondents, 32.1\%, were uncertain, while $32.31 \%$ percent disagreed with the statement. Ghanaian respondentse $^{\text {ee }}$ observations were similar to that of the responses of USA sample (strongly agreed and disagreed $34.7 \%$; strongly disagreed or disagreed $43.3 \%$; uncertain $22.1 \%$ ). In contrast $63.1 \%$ of respondents in the Nigeria study either agreed or strongly agreed, with only $20 \%$ disagreeing with the statement. Just only $16.69 \%$ were uncertain. Regarding item 28 it was the opinion of the majority of respondents in Ghana (61.54\%) that most consumers do not understand or appreciate the efforts made by manufacturers and dealers to satisfy their needs and wants, while $27.69 \%$ of the respondents either strongly disagreed or disagreed with only $10.77 \%$ were uncertain. In the Nigeria and USA study the trend was the same as majority respondents agreed to the statement $(76.4 \%$ and $73.4 \%$ respectively).

The response to item 29 indicate that a majority of the respondents (61.54\%) either strongly agreed or agreed with the suggestion that marketing activities must be more carefully regulated and controlled by government agencies for the protection of consumers. However, only $23.08 \%$ of the respondents either strongly disagreed or disagreed with statement and $6.15 \%$ were not certain. The Ghanaian respondents ${ }^{\text {ee }}$ observations were similar to the Nigeria results (with 63.1\% majority). In contrast in USA study majority (69.8\% respondents) disagreed with this statement

\section{Conclusions}

The findings of this survey indicated that the majority of respondents $^{\text {ee }}$ attitude towards marketing concept were 


\section{International Journal of Science and Research (IJSR) \\ ISSN (Online): 2319-7064}

Index Copernicus Value (2013): 6.14 | Impact Factor (2014): 5.611

positive, suggesting that the concept in principle is operating in Ghanaian businesses. On the concept dimensions and adequacy, which were made up of six statements majority of the sixty-five respondents agreed to these statements, indicating that the statements defining different aspects of the concept were appropriate. The majority of respondents also believe that the marketing concept is an idea that influence management philosophy and thought in Ghanaian firms. These include both small and large companies. Like the work in Nigeria [11], the Ghanaian employees "e survey revealed that although the marketing concept has been accepted, this does not seem to have been translated into actual consumer satisfaction or benefits in the marketplace. This view of respondents is supported by their observation that the concept relationship with consumerism could be an expanding challenge to those concerned with marketing, and that the spread of the marketing concept and the rise of consumerism are related developments in Ghana.

The major finding of this study is that the opinion of employees in Ghana toward the marketing concept operation in organizations confirms Barksdale and Darden and Mitchell and Agenmonmen [11] studies in USA and Nigeria respectively. Although Kuada and Buatsi [9] replication of market orientation studies by Jaworski and Kohli [6] and that of Appiah-Adu [1] work on marketing in emerging countries empirically showed that the marketing concept is in operation in Ghanaian businesses, this current work replicating Barksdale and Darden further render support to the operation of the marketing concept in Ghanaian businesses. Moreover the results of this study as analyzed and discussed above also show that employees confirms the assertion that elements of marketing concept have been around as long as trade itself [4]. This assertion renders credibility to Baker [15] observation that "marketing is marketing everywhere" and that in an attempt to develop marketing knowledge in the marketing system in Ghana "we should not neglect or overlook hard-won lessons from the past" (p. 1).

If this argument is approximately correct, it constitutes a major challenge for marketers in Ghana and emerging economies concerned with marketing and strongly suggests some questions that deserve further thought and research. For example, what are the problems encountered in applying the marketing concept on a day-to-day basis? What are the criteria for determining whether the marketing concept is in fact, being applied by an organization? Attempting to research into these issues would provide the basis for developing the knowledge base in this area of the marketing discipline in Ghana and emerging economies in general.

\section{References}

[1] Appiah-Adu, K.. "Marketing in emerging countries: evidence from a liberalized economy", Journal of Marketing Practice: Applied Marketing Science, 4 (4).118-129pp, 1998

[2] Bell, J. Doing your Research Project, Open University Press, Maidenhead, 2005.
[3] Barkslade, H. C., and B. Darden ,Marketers ${ }^{\text {ce }}$ Attitudes Toward the Marketing Concept ${ }^{\text {ee }}$, Journal of Marketing, 35, pp 29-36, 1971

[4] Brassington, F. and S. Pettitt Principles of Marketing, Harrow, England (4ed), FT Prentice Hall, 2006

[5] Houston, F. S. "What Marketing is and what it is not", Journal of Marketing. April, pp. 81-87, 1986

[6] Jaworski, B. J. and A. K. Kohli, "Market orientation: antecedents and consequences" Journal of Marketing, 57 (3), pp. 53-70, 1993

[7] Jobber, D., Principles and Practice of Marketing, London, (6ed), McGraw-Hall Higher Education, 2010

[8] Kohli, A. K. and Jaworski, B. J. "Market orientation: the construct, research propositions, and managerial implications", in Rohit Deshpandé, (ed.), Developing a market orientation', SAGE Publications, London, 1999

[9] Kuada, J. and Buatsi, S. N. "Market orientation and management practices in Ghanaian firms: revisiting the Jaworski and Kohli framework" Journal of International Marketing, 13 (1), pp. 58-88, 2005

[10] McGee, L. W. and R. L. Spiro, “The Marketing Concept in Perspective" Business Horizon, 1988.

[11] Mitchell, I. S. and A. I Agenmonmen,. "Marketers"e Attitudes Toward the Marketing Concept in Nigerian Business and Non-Business Operations", Columbia Journal of Marketing, 13 (1), Pp. 58 - 88, 1984

[12] Solomon, M. G. Bamossy, S. Askegaard, and M. K. Hogg, Consumer Behaviour: A European Perspective FT Prentice Hall, Harlow, 2010

[13] Williams. K. C. Behavioural Aspects of Marketing Butterworth Heineman, Oxford, 1998

[14] Wilmshurst, J. The fundamentals and practice of marketing. Butterworth Heinemann, Oxford, 1999

[15] Baker, M. J. "Marketing is marketing -everywhere!" Vikalpa. 30 (3), pp. 1- 9, 2005 